влади. В процесі спілкування дистанціювання може слугувати могутнім інструментом впливу на оточуючих; це свого роду мистецтво, що дозволяє як у прямому розумінні слова, так і абстрактно регулювати ступінь близькості/віддаленості співрозмовників, створюючи при необхідності непереборні перешкоди для захисту своєї території.

\title{
Література:
}

1. Ларина Т.В. Категория вежливости в английской и русской коммуникативных культурах. Москва : РУДН, 2004. 345 с.

2. Сахно С.Л. «Свое - Чужое» в концептуальных структурах. Логический анализ языка. Культурные концепты. Москва : Наука, 1991. C. 95-101.

3. Сепир Э. Культура подлинная и мнимая. Избранные труды по языккознанию и культурологии. Москва : Прогресс, 1993, С. 465-493.

4. Якобсон Р.О. Речевая коммуникация; Язык в отношении к другим системам коммуникации. Избранные работы. Москва : Прогресс, 1985. C. 306-330.

5. Brown P., Levinson S. Politeness: Some Universals in Language Usage. Cambridge : Cambridge University Press, 1987. 345 p.

6. Fowles, J. A Maggot. UK : Random House, 1996. 464 p.

7. Fowles, J. The French Lieutenant's Woman. UK : Random House, 2004. $448 \mathrm{p}$.

DOI https://doi.org/10.30525/978-9934-26-073-5-1-62

\section{АБРЕВІАЦІЙНІ ОСОБЛИВОСТІ АНГЛІЙСЬКИХ НУМЕРОНІМІВ В МОВІ СОЦІАЛЬНИХ МЕРЕЖ}

\author{
Ніколаєва Т. М. \\ кандидат філологічних наук, \\ дочент кафедри іноземної філологіі \\ Київського національного університету культури і мистецтвв \\ м. Київ, Україна
}

У роботі здійснено аналіз особливостей англійських нумеронімів як типу абревіації в мові соціальних мереж. Резюмовано, що за останнє десятиліття соціальні мережі придбали велику популярність в житті суспільства, а разом 3 ними з'явився новий сленг користувачів: лексика, в якій переважають скорочені форми слів, абревіатури. Установлено, що 232 
соціальна мережа - це не тільки джерело інформації, а й щоденний засіб комунікації, який надає користувачам широкі можливості самовираження. Спілкування в соціальних мережах здійснюється в умовах масової комунікації i, таким чином, має свої особливості на відміну від прямого спілкування в житті. Популярність і доступність інтернет технологій сприяла виникненню нових можливостей і способів комунікації, сформувавши нову сферу інформаційної взаємодії, яка привела до виникнення нових абревіацій в соціальних мережах.

Встановлено, що абревіатура як продукт способу скорочення зазвичай складається з комбінації букв, узятих у різних поєднаннях зі скорочуваного слова або словосполучення. Цим засобом послуговуються в усіх письмових жанрах, його використання активізується завдяки електронним носіям обміну інформацією (е.g., etc., NB, asap). Виявлено, що 3 популяризацією інтернету та соціальних мереж, значного поширення в англійській мові останнім часом набули нумероніми - слова, які утворені за допомогою числа. Часто вимова чисел і букв збігається 3 вимовою слів: 2DAY - today, 4E - forever, O4U - only for you, D8 - date, L8R - later. B великих словах іноді пишуть першу і останню літеру, а між ними число, яке позначає скільки букв пропущено, наприклад: $\mathrm{i} 18 \mathrm{n}-$ internationalization.

Проаналізовано, що у загальному розумінні «numeronym»- це слово, в якому число використовується для утворення абревіатури. Вимова букв і цифр може звучати так само, як і повне слово: «К9» замість «собачий» (фонетично: «kay» + «дев'ять»). В якості альтернативи, букви між першою і останньою замінюються числом, що становить кількість пропущених букв, наприклад «і18n» для «інтернаціоналізації». Іноді остання буква також вважається і опускається. Конкретизовано, що у скороченнях використовується комбінація букв і чисел, тобто алфавітночислова абревіація. Число 2 використовують для позначення прийменника to, прислівника too, префікса to-: 2day (today), L2M (listening to music), N2M (not to mention).

Проблема утворення нумеронімів знайшла відображення в науковій літературі. Так, досліджено особливості перекладу абревіатур, акронімів і скорочень (О. Бондаренко [1]); типи абревіатур та їх функціонування в терміносистемі митної справи (В. Дейнека [2]); абревіацію сучасної англійської мови (Л. Денисюк [3]); інновації в словниковому складі англійської мови початку XXI ст. : англо-український словник (Ю. Зацний [4]); функції абревіацій в сучасній англійській мові (С. Кісіль [5]); перекладацькі аспекти сучасних англійських абревіацій (Т. Ніколаєва [6]); особливості використання результатів контрастивних досліджень у перекладознавстві (А. Сітко [7]); перекладацьку неточність 
у перекладі фахового контенту веб-сайтів (І. Струк [8]). Проте проблема застосування нумеронімів як типу абревіації в соціальних мережах не знайшла належного відображення в сучасних публікація провідних дослідників.

Абревіація як лінгвістичне явище зустрічається в різних стилях мови, виявляється в текстах різноманітного характеру. Сучасний світ Інтернету і міжкультурної комунікації відрізняється використанням англомовних скорочень, що вимагає коректного трактування скорочень сучасної англійської мови.

Визначення скорочень і принципи їх класифікації $є$ дещо проблематичним, оскільки до теперішнього часу не вироблено ні універсального визначення, ні універсальної теорії абревіації. Оскільки слово бере участь в процесі абревіації безпосередньо, воно $\epsilon$ зручною одиницею аналізу для вимірювань абревіації. При цьому зазвичай враховують такі ознаки слова, як номінативність, двобічність, функціональність.

Зроблено висновок, що нині великого поширення в англійській мові набули нумероніми - слова, які утворені за допомогою числа. Часто вимова чисел і букв збігається з вимовою слів: 2DAY - today, 4E forever, O4U - only for you, D8 - date, L8R - later. В великих словах іноді пишуть першу і останню літеру, а між ними число, яке позначає скільки букв пропущено, наприклад: i18n - internationalization [6, с. 1

Результати дослідження показали, що вимова букв і цифр може звучати так само, як і повне слово: «К9» замість «собачий» (фонетично: «kay» + «дев'ять»). В якості альтернативи букви між першою i останньою замінюються числом, що представляє кількість пропущених букв, наприклад «i18n» для «інтернаціоналізації». Іноді остання буква також вважається і опускається. Ці скорочення слів іноді називають буквено-цифровими скороченнями або числовими скороченнями.

За підсумками аналізу було встановлено, що число також може позначати, скільки разів символ до або після його повторення. Зазвичай це використовується для представлення імені або фрази, в якій кілька послідовних слів починаються з однієї і тієї ж букви, як в W3 (World Wide Web) або W3C (World Wide Web Consortium). Деякі нумероніми повністю складаються з цифр, наприклад, «212» - «житель Нью-Йорка», «4-1-1» - «інформація», «9-1-1» - «допомога» і «101»- «базовий ». введення в тему »

Встановлено, що у скороченнях використовується комбінація букв і чисел, тобто алфавітно-числова абревіація. Число 2 використовують для позначення прийменника to, прислівника too, префікса to-: 2day (today), L2M (listening to music), N2M (not to mention). Так само число 4 
може замінювати прийменник for i морфему - fore: B4 (before). Число 8 використовують для позначення морфем -еat або -ate: GR8 (great), L8R (later), M8 (mate). Майже всі цифри можуть ставати частиною скорочення: N-E-1 ER anyone here?; NE1 anyone; N-E-1 anyone; $\mathrm{X}-1-10$ exciting.

Згідно 3 результатами дослідження числа іноді $\epsilon$ цілком еквівалентним математичним способом запису лексичної інформації про відомі факти та події: $24 / 7$ означає «весь час» (all the time), тобто двадцять чотири години на добу і сім днів на тиждень; Скорочення 9 / 11 пов'язують із терористичною атакою на ньюйоркські будівлі-близнюки 11 вересня 2001 року, є абсолютно всім зрозумілим маркером тих трагічних подій. Наявні тисячі подібних скорочень, які в зарубіжних джерелах називаються чат-абревіатурами [10].Результати нашого дослідження показали, що функція абревіатури і скорочення лексичних одиниць в процесі комунікації полягає в більш економному вираженні думки i усунення надмірності інформації. Учасники віртуального спілкування використовують велику кількість скорочених одиниць не тільки для того, щоб зменшити обсяг тексту. Тяжіння до незвичайності і нестандартності форми спілкування $є$ ще однією причиною поширення скорочень i абревіатур в чатах і комп'ютерних іграх. При живому спілкуванні передача великого обсягу інформації займає декілька секунд. При листуванні в Інтернеті, щоб висловити, навіть коротку думку доведеться витратити хвилину, а то і більше. В даному випадку приходять на допомогу різноманітні скорочення. Нині великою популярністю в англійській мові користуються нумероніми - слова, які утворені за допомогою числа. Часто вимова чисел і букв збігається 3 вимовою слів: 2DAY - today, 4E - forever, O4U - only for you, D8 - date, $\mathrm{L} 8 \mathrm{R}$ - later.

Перспективою данного дослідження $\epsilon$ можливе висвітлення семантико-лексичних особливостей нумеронімів в інших сферах стилістично маркованой лексики сучасної англійської мови.

\section{Література:}

1. Бондаренко О. Особливості перекладу абревіатур, акронімів i скорочень. Теоретичні й прикладні проблеми сучасної філологї̈. 2014. № 1. С. $76-83$.

2. Дейнека В. Типи абревіатур та їх функціонування в терміносистемі митної справи. Науковий вісник Волинського наиіонального університету ім. Лесі Українки. 2011. № 5. Ч. 2. С. 137-141.

3. Денисюк Л. Абревіація сучасної англійської мови. Нова педагогічна думка. 2015. № 1. С. 63-65. 
4. Зацний Ю., Янков А. Інновації в словниковому складі англійської мови початку XXI ст. : англо-український словник. Вінниця : Нова книга, $2008.360 \mathrm{c}$.

5. Кісіль С. Функції абревіацій в сучасній англійській мові. Освіта, наука та виробництво: розвиток $i$ перспективи : матеріали I Bceукраїнської науково-методичної конференції, м. Шостка, 21 квітня 2016 р. Суми : СумДУ, 2016. С. 76-77.

6. Ніколаєва Т. М. Перекладацькі аспекти сучасних англійських абревіацій. Науковий вісник Міжнародного гуманітарного університету. 2018. № 37. С. 107-110.

7. Сітко А. В. Використання результатів контрастивних досліджень у перекладознавстві. Наукові записки. Серія : Філологічні науки (мовознавство). 2013. Вип. 116. С. 199-203.

8. Сітко А., Струк І. Перекладацька неточність у перекладі фахового контенту веб-сайтів. Гуманітарна освіта в технічних вищих навчальних закладах : зб. наук. пращь. Київ: Університет «Украӥна». 2018. № 37. C. $67-74$.

9. Numeronym. URL: http://en.wikipedia.org/wiki/Numeronym (last accessed: 05.04.2021).

10. Leet. URL: http://ru.wikipedia.org/wiki/Leet (last accessed: 05.04.2021).

DOI https://doi.org/10.30525/978-9934-26-073-5-1-63

ФУНКЦІОНАЛЬНІ ОСОБЛИВОСТІ

\title{
ТЕРМІНОСИСТЕМИ ПОДАТКОВОГО ЗАКОНОДАВСТВА
}

\author{
Охріменко О. А. \\ кандидат філологічних наук, \\ старший викладач кафедри романо-германської філології \\ Національного педагогічного університету імені М. П. Драгоманова \\ м. Київ, Украӥна \\ У лінгвістичній літературі неодноразово зазначалося, що словни- \\ ковий склад мови складається 3 низки взаємопов'язаних «тематично \\ обмежених сукупностей спеціальних і загальних мовних засобів, які \\ використовуються у певній сфері людської діяльності». Усебічне дослі- \\ дження словникового складу мови було й залишається однією 3 най- \\ важливіших проблем мовознавства. Нерозривний і постійний зв'язок
}

